This item was submitted to Loughborough's Research Repository by the author.

Items in Figshare are protected by copyright, with all rights reserved, unless otherwise indicated.

\title{
The role of the Sydney Gazette in the creation of Australia in the Scottish public sphere
}

PLEASE CITE THE PUBLISHED VERSION

https://www.routledge.com/Historical-Networks-in-the-Book-Trade/Feely-Hinks/p/book/9781848935891

\section{PUBLISHER}

(c) Routledge

VERSION

AM (Accepted Manuscript)

\section{PUBLISHER STATEMENT}

This work is made available according to the conditions of the Creative Commons Attribution-NonCommercialNoDerivatives 4.0 International (CC BY-NC-ND 4.0) licence. Full details of this licence are available at: https://creativecommons.org/licenses/by-nc-nd/4.0/

\section{LICENCE}

CC BY-NC-ND 4.0

\section{REPOSITORY RECORD}

Beals, M.H.. 2019. "The Role of the Sydney Gazette in the Creation of Australia in the Scottish Public Sphere". figshare. https://hdl.handle.net/2134/21443. 


\title{
Note: This is a preprint version of an essay accepted for the forthcoming edited collection John Hinks and Catherine Feely (eds.), Historical Networks in the Book Trade (2014)
}

\section{THE Role of the Sydney GazetTe IN the CREATION of Australia IN THE SCOTTISH PUBLIC SPHERE}

\author{
M. H. Beals ${ }^{1}$
}

'We feel highly flattered in perceiving that articles are occasionally copied from the Sydney Gazette, into the best conducted Journals as well of Great Britain as of India'.

The Sydney Gazette and New South Wales Advertiser, 2 January 1819

George Howe was a newspaper man, and his life, like his trade, stretched haphazardly across the late-Georgian empire. Born on St Kitts to Thomas Howe, government printer at Basseterre, the young Howe was himself apprenticed to the West Indian printing trade before departing for London in 1790 to pursue a career in journalism. There, he worked for The Times and other English newspapers until his unfortunate incarceration-for shoplifting-in 1799 and his subsequent transportation to New South Wales. ${ }^{2}$ His previous employment proved immediately advantageous and he was assigned to operate the government printing press on behalf Governor Philip Gidley King. Soon after his appointment, the governor found it 'desirable that the settlers and inhabitants at large should be benefitted by useful information being dispersed among them' and allowed Howe to return to his former profession. ${ }^{3}$ From then until his untimely death in 1821, rumours and reportage from his Sydney Gazette trudged steadily along the empire's labyrinthine news networks, becoming the primary source of Australian intelligence in the Scottish press. Thus, by mere happenstance, an emancipated convict from the western edge of the British Empire, living ten thousand miles from the island of his birth, became the voice of Australia in a country he never visited.

Within an Australian context, the Sydney Gazette is not without its biographers. In an effort to understand colonial and provincial presses beyond their subservience to London, British and Commonwealth historians of the twentieth century focused their attention on specific regions or titles, including the Gazette, isolating them from the wider networks to which they belonged. ${ }^{4}$ Over the past decade, however, the Antipodes have begun to reclaim their place within imperial press history. Alan Lester, in particular, has highlighted the necessity of moving

\footnotetext{
${ }^{1}$ The author would like to express gratitude to Tanja Bueltman, Lisa Chilton, Marion Diamond, Amy Lloyd, Marjory Harper, and Antony Taylor for their insightful comments on earlier incarnations of this work as well as to Brett Holman, Yvonne Perkins, Phillip Sheldrick, and Wendy Ugolini for their assistance in locating key texts.

2 J. V. Byrnes, 'Howe, George (1769-1821)' Australian Dictionary of Biography Volume 1: 1788-1850, A-H (Melbourne: Melbourne University Publishing, 1966), pp. 557-9.

${ }^{3}$ Victoria Goff, 'Convicts and Clerics: Their Roles in the Infancy of the Press in Sydney, 1803-1840', Media History, 4 (1998), 101-120 (p. 103).

4 Phyllis Mander Jones, 'Australia's First Newspaper', Meanjin, 12 (1953), 35-46.; Denis Cryle, 'Researching Media History: National and Global Perspectives', Media History, 5 (1999), 65-70 (pp. 66-8).
} 
beyond institutional biographies and national narratives to fully explain the nature and meaning of editorial content. ${ }^{5}$ His conclusion, that a shared sense of settler identity was legitimised and reinforced within a multi-polar public sphere, was later refined by Christopher Holdridge, whose separate, but equally multi-polar network, offered an important counterpoint to Lester's while continuing to stress the importance of inter-colonial dialogues. ${ }^{6}$ Yet, in many ways, these studies catapult into the middle of a much longer and broader narrative. Connections within the imperial public sphere, including Britain's antipodean colonies, began not at the dawn of the Victoria's reign, but forty years prior with the genesis of Australian journalism and expansion of Britain's provincial press. In spite of this, these early years of Australian journalism have received relatively little notice outside isolated institutional or personal biographies and the nature of Georgian press networks have been rarely examined beyond direct personal or kin connections. ${ }^{7}$ This essay will therefore expand the British-AfricanAustralasian triptych by shifting our attention backwards, to the turn of the nineteenth century, and northwards, to the rapidly expanding news networks of Scotland.

Although the number of Scottish periodicals had grown exponentially since the 1780s, developing a robust network for collaboration and debate, until 1821, the Sydney Gazette was the only Australasian periodical to wend it way across this imperial network. Formally established in 1803, the Gazette owed this initial dominance to a lengthy monopoly within Australasia; however, its close identification with government policy, and government censorship, left it open to pejorative branding, such as 'the government paper'. ${ }^{8}$ It thus stands to reason that the Gazette offered Scottish readers little more than the government line, and might be summarily dismissed as mono-directional propaganda. Yet, until the untimely death of its founding editor, the Gazette acted as the primary gatekeeper of the Australasian narrative in the Scottish consciousness. It was through its uncorroborated reportage that Scottish readers first understood the daily toils of Britain's most distant settlement, its geography, its dangers and its allure. This did not, however, mean that it had the final word. As issues of the Gazette travelled along the edges of Britain's imperial press network, they were cut, copied and adulterated to fit the needs and desires of Britain's plagiarising presses. Moreover, once new presses were established in Australasia in the 1820s and 1830s, and Scottish settlers began to send word of their lives abroad, the Gazette could no longer claim a monopoly on the raw material.

Who, then, authored the public consensus on Australasia in the late Georgian empire-the Gazette, the London periodicals who received it first, or the Scottish editors who received both London and Australasian papers in tandem?

The answer depends greatly on which aspect of Australasian life is examined; different topics

\footnotetext{
${ }^{5}$ Alan Lester, 'British Settler Discourse and the Circuits of Empire', History Workshop Journal, 54 (2002), 24-48.

${ }^{6}$ Christopher Holdridge, 'Circulating the African Journal: The Colonial Press and Trans-Imperial Britishness in the Mid Nineteenth-Century Cape', South African Historical Journal, 62 (2010), 487-513.

${ }^{7}$ See for example Christine Y. Ferdinand, Benjamin Collins and the Provincial Newspaper Trade in the Eighteenth Century (Oxford University Press, 1997); Ralph Frasca, Benjamin Franklin's Printing Network: Disseminating Virtue in Early America, 1st edn (University of Missouri, 2006).

${ }^{8}$ Sandra Blair, 'The Felonry and the Free? Divisions in Colonial Society in the Penal Era', Labour History, 1983, 1-16 (pp. 4-6).
} 
took different paths and were handled in different ways. This study will therefore trace the individual paths of three specific tropes of colonial Australasia between 1803 and 1842, the years in which the Sydney Gazette was in operation. By examining how Australasians described colonial life, and by tracing these descriptions through reprints, abridgements and commentaries within the Scottish press, it will show that several overlapping networks operated simultaneously, with gatekeepers in Sydney, London and Scotland's central belt, each of whom contributed to the public consensus surrounding the land of 'convicts and kangaroos. ${ }^{9}$

\section{Methodology}

In order to understand the role of an institution such as the Sydney Gazette, careful study must first be made of its relationships. In Reading Newspapers, Heyd contends that the purpose, or role, of a newspaper can be largely understood through an examination its introductory issue, which typically provided a mission statement or 'manifesto' ${ }^{10}$ Yet, this initial declaration represents only its intended role. ${ }^{11}$ The Gazette's declaration that "Information is our only Purpose" would have been meaningless if it had not been able to secure the relationships necessary to obtain content or the distribution system to deliver it. ${ }^{12}$ Moreover, as the resources and priorities of its editors changed, its actual impact on the people of New South Wales and the wider British Empire deviated considerably from this stated purpose. Therefore, we must first understand the how the Gazette connected to the imperial public sphere before we can draw any conclusions as to its role within it.

Although familial and commercial partnerships shed some light on possible mechanisms for gathering and disseminating news content, they are insufficient to explain the practicalities of this movement; how precisely did garbled, half-paraphrased Gazette articles find their way into the papers of Scottish market towns and who was responsible for composing their final form? In the end, we cannot understand the role of the Gazette without also exploring the roles of the intermediary nodes within its wider dissemination network. As a complete understanding of all nodes within this network is not possible in such a short space, this study will limit its examination to their roles in developing a public consensus on what may now be considered three tropes of colonial Australasia: redeemed convicts, savage cannibals and wicked bush rangers. Moreover, as a newspaper's role is largely defined by the influence it wields, influence will be quantified, however crudely, to form a basis for comparison.

Ideally, an assessment of influence takes into account both the extent to which opinions were broadcast and the extent to which they were received, or assimilated, by consumers. Traditionally, a discussion of editorial content and public opinion is conducted through a qualitative analysis of a complete or representative sampling of periodicals. However, this methodology tells us little about the relative influence these writings had. It demonstrates

\footnotetext{
${ }^{9}$ The Edinburgh Review, or Critical Journal: For July 1819-October 1819, 1819, xxxII, p. 28.

10 Uriel Heyd, Reading Newspapers: Press and Public in Eighteenth-century Britain and America, SVEC, 2012:03 (Oxford: Voltaire Foundation, 2012), p. 31.

${ }^{11}$ For a fuller explanation of Institutional Role Theory, see J. C. Wood, Defining the Role of the African Union Peace and Security Architecture (APSA): A Reconceptualisation of Institutional Roles, Ph.D. Dissertation, Coventry University, 2013, pp. 53-61.

${ }^{12}$ The Sydney Gazette and New South Wales Advertiser (Hereafter SG), 5 March 1803.
} 
merely that an opinion existed, not that it was generally held, or even that it originated with a particular advocate. For example, Macmillian's Scotland and Australia draws several erroneous conclusions regarding the Edinburgh Evening Courant because he failed to realise that many of its articles were direct transcriptions from the Scotsman. ${ }^{13}$ Moreover, although discourse analysis can provide significant insights into a text, as can biographical and geographical context, these qualitative discussions remain fundamentally focused on the broadcaster, and why the piece was created, rather than the recipients, and the extent to which it shaped their view of the topic. Therefore, influence must recognise the extent to which editorial content was accepted or dismissed by consumers. Although the ability to quantify assimilation by individual subscribers remains elusive, assimilation by institutional subscribers, that is, by other periodicals, can be determined.

This is done by the establishing dissemination pathways. The period before 1840 was plagued by scissors-and-paste journalism, wherein newspapers reused text from others with little or no revision. ${ }^{14}$ Indeed, it was not until long after the passage of the 1842 Copyright Reform Act, which made plagiarism more dangerous, and the dominance of international telegraphy, which made it unnecessary, that the scissors-and-paste method began to disappear. ${ }^{15}$ It was so prevalent at mid-century that one Auckland newspaper apologised for its delayed publication by jesting that the editors were 'nearly all unaccustomed to the use of scissors.' ${ }^{16}$ By noting where edits were maintained, discarded or further altered, sources and copies can be identified and pathways mapped. By determining which titles created the most enduring content, either through initial reportage or significant modification, in-depth discourse and literary analysis can be undertaken with a greater sense of overall influence. It is hoped that subsequent studies will compare these analyses with perceptions of Australia in other written records, such as literary texts and personal writings, so that a clearer understanding of the role of these publications in shaping public opinion can be obtained.

This study utilised manual transcriptions of nine Scottish periodicals-the Glasgow Herald, Caledonian Mercury, the Scotsman, the Edinburgh Advertiser, the Aberdeen Journal, the Berwick Advertiser, the Kelso Mail, the Dumfries Weekly Journal and the Dumfries and Galloway Courier-and focused exclusively on those articles that discussed the aforementioned tropes before 1842 and the closure of the Sydney Gazette. As articles were discovered through both digital searches and manual examination, it is likely that relevant articles were excluded; however, nearly six-hundred individual pieces were obtained, offering a significant sample from

13 David S. Macmillan, Scotland and Australia, 1788-1850: Emigration, Commerce and Investment (Oxford: Clarendon Press, 1967), p. 59. See, for example, Scotsman, 28 July 1827 and Edinburgh Evening Courant, 30 June 1827.

${ }^{14}$ Catherine Feely, 'Scissors and Paste Journalism', Dictionary of Nineteenth Century Journalism in Great Britain and Northern Ireland, ed. by Laurel Brake and Marysa Demoor (London: Academia Press, 2009), p. 561.

${ }^{15}$ Unlike publishers, newspapers were in little danger of successful prosecution in the nineteenth century, though some cases were brought before the judiciary. Catherine Seville, Literary Copyright Reform in Early Victorian England: The Framing of the 1842 Copyright Act (Cambridge: Cambridge University Press, 1999), pp. $249-50$.

${ }^{16}$ Ross Harvey, 'Bringing the News to New Zealand: The Supply and Control of Overseas News in the Nineteenth Century', Media History, 8 (2002), 21-34 (p. 24); For a discussion of the impact of the telegraph on scissors-andpaste processes, see Roger Neil Barton, 'New Media: The Birth of Telegraphic News in Britain 1847-68', Media History, 16 (2010), 379-406 <doi:10.1080/13688804.2010.507475>. 
which to develop conclusions. ${ }^{17}$ The texts were initially compared digitally, through a computerised comparison of five-word nGrams, which were in turn compared manually to determine accuracy and directionality. In the majority of cases, clear lines of dissemination were evident; connections that are ambiguous have been noted. It is acknowledged that the selection of periodicals is not exhaustive and that alternative networks, such as those discussed by Lester and Holdridge, are likely to exist; however, additional newspapers were selectively examined for any articles with explicit attributions to them. Finally, although the Glasgow Herald and Dumfries Weekly Journal were examined, their limited commentary and their nearisolation from the other newspapers, suggests the existence of a separate western network that merits separate consideration. ${ }^{18}$

Through these pathways, this study will demonstrate the role of the Sydney Gazette in the formation of public opinion regarding Australasia, and the extent to which its opinions and representations were maintained and widely disseminated in Scotland.

\section{Wider Network Construction}

Despite being common tropes, viewing convicts, cannibals and bush rangers in isolation would not only run the risk of misinterpretation, it would deny us an answer to a crucial question; did sensationalism behave differently from hard news? It is only in contrast with the wider network that we can understand the importance of these particular dissemination pathways, and from this wider perspective, the role of the Sydney Gazette is surprisingly clear. It was the primary creator of the Australasian content in the Scottish press before 1825. For the remainder of the 1820s, it shared this role with the Australian, another Sydney newspaper, which had recently broken the Gazette's monopoly. By 1829, no single source maintained dominance in the creation of Australasian content. Instead, a variety of periodicals, alongside a steady flow of personal correspondence, provided raw material to Scottish editors. Yet, this narrative does not properly account for these shifts; it was not availability, but ideology and a desire for authenticity that prompted Scottish editors to diversify their sources.

The first Australasian story to be published in Scotland after 1803 appeared in the Caledonian Mercury on 20 July 1805, over two years after the Gazette's first issue, and more than three since the Mercury's last mention of New South Wales. The piece was a compilation of items from the Gazette's December and January issues, truncated but precise transcriptions of Howe's text without any additional commentary. ${ }^{19}$ In these early years, the Gazette's effect on the dissemination of Australasian news is immediately clear. In the previous two decades, Scotland published only a handful of pieces on the colony. In the following two decades, over one hundred appeared in the Scottish press, the annual occurrence increasingly steadily until 1817.

For these twenty years, almost all news content travelled from Sydney to London, where it was published in a variety of formats by a number of different periodicals; the most important of

\footnotetext{
${ }^{17}$ Articles composed exclusively of shipping or military intelligence have been excluded from the analysis; the former owing to the generic nature of the text and the latter owing to its official (homogeneous) dissemination.

${ }^{18}$ A similar conclusion was made in Macmillan, pp. 61-2. Discussions of these papers, except were illustrative of the eastern network, will be reserved for future analysis.

${ }^{19}$ Caledonian Mercury (Hereafter CM), 20 July 1085; SG, 9 December 1804; 16 December 1804, 6 January 1805.
} 
which, for this study, were the Morning Chronicle and Daily Advertiser and the Morning Post. From here, it travelled to Edinburgh, with some exceptions explored below. The primary Edinburgh hub was the Mercury, which, in turn, had copied almost exclusively from the Chronicle. Indeed, the apparent reliance of the Mercury on the Gazette seems to originate entirely from its actual dependence on the Chronicle, who, in turn, relied up on the Gazette-a distinction that had significant repercussions in later years. After 1818, the Scotsman began to publish Antipodean intelligence as well. Its content, excluding a significant number of parliamentary debates, was almost entirely derived from the Mercury, or from the Chronicle directly.

Of the other Scottish journals examined, most received their pre-1825 news from the Mercury. Although the material was primarily written by Howe in Sydney, and abridged by the Chronicle in London, the Mercury still played an important role in this pathway. On numerous occasions, it further truncated the information it had received from the Chronicle or added additional commentary, and this additional material, written in Scotland, was then transmitted to the Borders or the northeast. This should not, however, imply that the Chronicle and Mercury were the only pathways for these presses. Indeed, their London subscriptions appear to have been with the more conservative Morning Post. Because the Chronicle, Mercury and Scotsman espoused Whig politics, it is tempting to link the Kelso Mail's use of the Post to its editors' Tory affiliation; yet, the same cannot be said for the radical Berwick Advertiser or the Godly, but otherwise moderate, Aberdeen Journal, both of whom turned to the Post on at least one occasion, as did the Mercury. ${ }^{20}$ More importantly, in none of these cases did the British editors have any role in the composition of the text; the four reprints (excluding duplications) were transcriptions from the Gazette with no additional commentary provided by the Post. All roads, indeed, led back to Sydney.

After the founding of the Australian in 1824, the first non-governmental periodical to be published in Sydney, content shifted in two important ways. First, the Australian quickly overtook the Gazette as provider of Antipodean news in both the Mercury and the Scotsman. More importantly, both Edinburgh papers compiled their own digests and reprints of the newcomer, rather than rely on the Chronicle or Post as an intermediary. Indeed, the few remaining appearances of the Gazette always appeared via London periodicals. ${ }^{21}$ In conjunction with this direct access to Australasian newspapers, there was an increasing use of emigrant correspondence by the eastern newspapers. Particularly striking is that the majority of letters were addressed to individuals in Midlothian, rather than to English recipients. The nearexclusive use of Scottish correspondence had several effects, including a rapid increase in the amount of information available regarding Port Philip. This settlement, much to the evident delight of the Edinburgh editors, was regarded as being 'essentially a Scotch colony'. ${ }^{22}$ This assessment is not without criticism, but this anecdotal image, buttressed by locally received

\footnotetext{
${ }^{20}$ Kelso Mail (Hereafter KM), 26 August 1822; The British Chronicle and Berwick Advertiser (Hereafter BA) 29 January 1820; Aberdeen Journal (After AJ), 15 December 1819 and 29 October 1823; CM, 11 December 1819.

${ }^{21}$ See, for example, Scotsman, 24 October 1832 and CM, 14 May 1835.

${ }^{22}$ Scotsman, 7 November 1840; CM, 7 November 1840.
} 
correspondence and locally published guides, was clear. ${ }^{23}$ Although the Gazette continued to be available, directly and through London reprints, Scottish editors made a conscious effort to obtain authentic intelligence from colonists rather than the colonial government, and from Scottish colonists who were 'personally known' ${ }^{24}$

Thus, the role of the Sydney Gazette in the wider network was to provide raw material for the London dailies. Because of the existing relationship between the provincial and metropolitan presses, it also shaped the nature of Scottish reportage, but only until Scotland developed independent links with Australia. At this stage, its significance in the Scottish public sphere diminished until it ceased publication altogether in 1843. But do these general trends hold true for the emotive triumvirate of convicts, cannibals and crime?

At first glance, the Gazette offered Scotland precisely what it was looking for in those early years. Despite existing in wholly dissimilar environments, the editorial tone of the Gazette and its re-printers in Britain seem surprisingly congruous. Although many argued that the Gazette's role as an official publication impaired its objectivity in matters political, and made it timid in matters controversial, both it and its Scottish re-printers appear to have agreed that sensationalism was an effective editorial strategy. ${ }^{25}$ Stories of 'fires, boating accidents, murders, robberies, rapes, convict escapes, trials, and executions' appeared frequently within the original publication and were among the most likely to be reprinted before $1825 .^{26}$ Indeed, accounts of colonial society and politics, of the heated conflict between emancipists and exclusives, were rarely noted in the Scottish press. ${ }^{27}$ Yet, sensational accounts of convicts and cannibals may simply have been the best that the Gazette had to offer, rather than indicative of what the Scottish press desired.

\section{Redemption}

Fifteen years after its foundation, New South Wales was still primarily viewed a penal colony. Its purpose was to provide punishment, and perhaps redemption, for undesirable British subjects whose crimes were not sufficiently serious to warrant death, but whose incarceration would have strained the penal system past the breaking point. As predominantly English undesirables, they received relatively little notice in the Scottish press, often appearing merely

\footnotetext{
${ }^{23}$ For assessments of the 'Scottishness' of Port-Philip, see Cliff Cumming, 'Scottish National Identity in an Australian Colony', The Scottish Historical Review, 72 (1993), 22-38 and A. G. L. Shaw, A History of Port Phillip District: Victoria Before Separation (Melbourne: Melbourne University Publishing, 2003), pp. 101-2. A key publication promoting this view was David Lindsay Waugh and James Waugh, Three Years' Practical Experience of a Settler in New South Wales: Being Extracts from Letters to His Friends...from 1834-1837 (Edinburgh: John Johnstone, 1838). Extracts from this text were published in CM, 27 August 1838 and Scotsman, 11 April 1838.

${ }^{24}$ Scotsman , 13 April 1842.

${ }^{25}$ For examples of contemporary condemnations of the Gazette, see David Blair, The History of Australasia: From the First Dawn of Discovery in the Southern Ocean to the Establishment of Self-Government in the Various Colonies, Comprising the Settlement and History of New South Wales, Victoria, South Australia, Tasmania, and New Zealand, Together with Some Account of Fiji and New Guinea (Glasgow: McGready, Thompson \& Niven, 1878), p. 325; Charles White, Convict Life in New South Wales and Van Diemen's Land (White, 1889), p. 41.

${ }^{26}$ Goff, p. 104.

27 The key exception to this is the right to a legislative assembly and trial-by-jury, which were noted in the Scottish press, but only briefly. See, CM, 9 September 1819 and 17 July 1833.
} 
as statistics on disembarkation or death. ${ }^{28}$ This lack of commentary on transportation, and the fate of the transported, contrasted sharply with passionate judicial and popular opinion in Scotland, which deemed the practice immoral-an opinion stemming, perhaps, from the region's particular experience of the system during Cromwell's republic and, more recently, with the conviction of the 'Scottish Martyrs' ${ }^{29}$ On the other hand, this paucity of debate did reflect the cautious stance taken by Howe. Despite his personal experiences, and his strong advocacy of the emancipationist cause within New South Wales, the Gazette never actively debated the moral and social implications of transportation or the question of emancipists' rights. $^{30}$ This conspicuous absence of material prompted Scottish editors to expand their search beyond the Gazette and into Australasian correspondence and parliamentary debates. The results of these searches, however, were rarely disseminated beyond Edinburgh.

In the early 1810s, the Mercury painted an ambivalent, and uncontested, picture of Australian society-occasionally suspicious, occasionally amused-through a series of brief summaries and extracts. One of the earliest accounts, a letter from an Indian merchant, quipped that although Sydney's population was advancing rapidly, 'You may judge what they principally consist of [...] and you will be surprised when I acquaint you I have sat at the Governor's table with highwaymen, and some characters less honourable, but who now hold some lucrative offices under the Crown. ${ }^{31}$ This inverted society, where 'emeritus felons' became wealthy landowners and respected magistrates, remained a popular and unsettling conception of the colony for much of the nineteenth century. ${ }^{32}$ Another commentary, taken from the Gazette, contemplated the redemption of Thomas West, pardoned in 1801 for 'his general good conduct' and, more importantly, for his construction of the colony's first water mill. ${ }^{33}$ These early accounts were sourced by the Mercury itself, suggesting it had a greater interest in redemptions, even ludicrous ones, than its London counterparts. Indeed, the first convict-related article to be taken from the Chronicle was primarily statistical, though it did provide a somewhat disturbing description of a suicide en route: 'On Tuesday arrived the ship Friendship, Captain Armet, with 97 female prisoners, having lost four on the passage, Anna Beal, Sarah Blower, Martha Thatcher, and Jane Brown, the last of whom, from a sudden irritability of temper, threw herself overboard, and was drowned. ${ }^{34}$ This unpitying portrayal of transportation suggests that the Chronicle's editor, like many English authorities, hoped to emphasise 'the severity of punishment rather than the possibility of reform' ${ }^{35}$ A later Chronicle account, taken from the Gazette and reprinted in the Mercury, Scotsman and Berwick Advertiser, described the convicts, not with reserved or bemused detachment, but with a palpable anxiety. In 1818 , colonists feared that military forces were spread far too thinly, leading to a consensus that

\footnotetext{
${ }^{28}$ For an illustrative example, see $C M, 30$ November 1818.

${ }^{29}$ Macmillan, pp. 28-9.

${ }^{30}$ Sandra Blair, pp. 5-6.

${ }^{31}$ CM, 26 May 1814.

32 Thomas Carlyle to James Johnston, Edinburgh, 4 February 1822, Carlyle Letters Online, DOI: 10.1215/It18220204-TC-JJ-01; CL 2: 28-31; John Hirst, Freedom on the Fatal Shore: Australia's First Colony (Melbourne: Black Inc., 2008), pp. 176-183.

${ }^{33} \mathrm{CM}, 7$ November 1814.

${ }^{34}$ The Morning Chronicle and Daily Advertiser (Hereafter MC), 23 November 1818; CM, 30 November 1818.

${ }^{35}$ Richard White, Inventing Australia: Images and Identity, 1688-1980 (Sydney: Allen \& Unwin, 1981$)$, p. 17.
} 
a King's vessel should be again stationed in the harbour, as a protection against the easy possibility of outward assault, and to frustrate the numerous combination of the prisoners, who are ever forming plans, and often too successfully, to carry away the colonial craft... ${ }^{36}$

This piece, combining sensationalism and the on-the-ground authenticity of the Gazette, was the first to be widely distributed outside Edinburgh.

The next significant wave of interest came in 1819, in the wake of Henry Grey Bennet's Letter to Viscount Sidmouth, which lamented the ineffectiveness of the transportation system, financially and morally. ${ }^{37}$ Alone among its rivals, the Scotsman published extensive accounts of the Commons debate, allocating over five columns of text to the subject, including a full front-page commentary of its own composition that referred to Bennet as 'this excellent individual'. ${ }^{38}$ Although it chose not to reprint the debate, its importance was also noted by the Berwick Advertiser, who supported Bennet's conclusion that the transportation system was 'wholly lost, as the means of preventing crime. ${ }^{39}$ Particularly noteworthy is that the Mercury, the principal commentator on convicts in the previous years, did not respond to the debate at all. It did print a brief account of the parliamentary debates, but did so with no obvious differentiation between it and the numerous other parliamentary proceedings in that issue. ${ }^{40}$ Indeed, it was not until the Edinburgh Review published excerpts from the Letter, many months later, that the Mercury's view can be somewhat ascertained. ${ }^{41}$ Although the Review included a lengthy critique of Bennet's Letter, the Mercury conspicuously removed this discussion from its reprint of the Review, focusing instead on the climate, exploration and society of the colony. ${ }^{42}$ This avoidance had the curious effect of the Mercury reprinting from the Review a large amount of material that it had already published the summer before, when it had been taken directly from the Gazette. ${ }^{43}$

That it chose not to engage with Bennet's condemnation did not preclude the Mercury from continuing its earlier debate on the redemption of convicts once they had arrived. In 1821, an account from an unnamed minister from Parramatta appeared in the Scottish press, stating that 'Every week I ride, during the night, several miles along a road on which there are more than one hundred convicts employed, and I have never experienced the slightest molestation from them.' The original source of this account is unclear, but its dissemination is unusual. In August 1821, it appeared in the Mercury and was reprinted by the Dumfries Courier the following week. ${ }^{44}$ Several months later, it was printed in the Mercury for a second time and subsequently reprinted by the Aberdeen Journal. ${ }^{45}$ Thus, even when accidently repeated, direct

${ }^{36}$ MC, 28 November 1818; CM, 5 December 1818; Scotsman, 5 December 1818; BA, 5 December 1818.

37 Henry Grey Bennet, Letter to Viscount Sidmouth, Secretary of State for the Home Department, on the Transportation Laws, the State of the Hulks, and of the Colonies in New South Wales (London: J. Ridgway, 1819).

${ }^{38}$ Scotsman, 27 February 1819.

${ }^{39} B A, 27$ February 1819.

${ }^{40} \mathrm{CM}, 22$ February 1819.

${ }^{41}$ The Edinburgh Review, or Critical Journal, vol. 32, 1819, 28-47.

${ }^{42}$ CM, 9 September 1819.

${ }^{43} \mathrm{CM}, 1818$ July 16.

${ }^{44}$ CM 20 August 1821; The Dumfries and Galloway Courier, 28 August 1821.

${ }^{45}$ CM 25 October 1821; AJ 7 November 1821. 
Australasian voices were more likely to be reprinted than Scottish commentary or London abridgments.

Besides the above, the Mercury published six accounts of Australasian convicts in the 1820s. Three were letters sent to Midlothian recipients; the others were reprints of the Chronicle and London's Courier. The letters characterise the convicts as being proud, stubborn individuals, who chafe at their subservient place within colonial society. 'A convict' one noted 'cannot bear to be called by the name, but considers the name of prisoner much less opprobrious. ${ }^{46}$ Moreover, despite being 'easily excited', they were not nearly as dangerous as their conviction implied. The others, like that of the Parramatta missionary, sought to allay the fears of prospective emigrants, assuring them that 'Sydney is without exception the quietest town I was ever in, and you may walk through it at all times with as much safety as through the streets of Edinburgh. ${ }^{47}$ Such accounts reconciled easily with the writings of W. C. Wentworth and J. D. Lang, who hoped that free emigration would cause Australia's 'moral wilderness to blossom as the rose' and its reputation be restored, the latter having been greatly ridiculed for emigrating to the questionable colony. ${ }^{48}$

Throughout the 1820s, the duality of punishment and paradise saturated the Mercury's coverage of New South Wales. In 1824, the Chronicle printed a letter that aimed to counter the 'unblushing falsehoods of the convict delegates' to Parliament and explain the true condition of transported prisoners. Dutifully reprinted in the Mercury, its editor made plain his continuing impatience with Bennet's complaints. ${ }^{49}$ Indeed, by the end of the decade, the Mercury demonstrated even less sympathy for transported criminals than its metropolitan source. When a letter, written by a transported convict and published by the Chronicle, was reprinted in Edinburgh, it had one telling alteration: the Mercury omitted the original prefatory aim, to correct those who 'erroneously suppose that transportation is a bed of roses', and reframed the piece as simply a means of deterring Britons 'from the perpetration of crime. ${ }^{50}$ Yet, despite this lack of sympathy for Bennet's reforms, the Mercury maintained its portrayal of New South Wales as a settlement safe for free emigrants where, by judicious measures of the Governor [...] crime had wonderfully diminished, and the moral amendment of the convicts was rapidly gaining ground. ${ }^{51}$

The Scotsman of the 1820 s, in contrast, spoke only sparingly of transported convicts, its notices often nothing more than raw statistics. It did, however, occasionally revisit the idea of failed reformation. Commenting upon a notice in the Hobart Town Gazette, it noted that 'the measures adopted are not at all calculated to reform the convicts. Many of these wretched beings are treated with the utmost indignity, and, having no character to maintain, they

\footnotetext{
${ }^{46} \mathrm{CM}, 5$ January 1824.

${ }^{47}$ CM, 20 October 1825; CM, 19 June 1826.

${ }^{48}$ White, p. 33; Hirst, p. 177.

${ }^{49}$ MC, 24 June 1824; CM, 1 July 1824.

50 MC, 24 September 1829; CM, 12 October 1829. That some Britons had committed crimes in order to obtain a free passage to Australia was commonly cited by those who felt the transportation system an insufficient deterrent. White, p. 30.

${ }^{51}$ Courier, 8 August 1823; Edinburgh Advertiser (Hereafter EA), 15 August 1823; CM, 18 August 1823.
} 
become reckless and desperate in crime. $^{, 52}$ A few years later its appraisal was neatly summarised by an inserted letter:

The convict population are all well fed, well clothed, very indolent, and very miserable--trading, cheating, canting, lying, praying, swearing, drinking, dissipating; being every thing but what they might be in this land of abundance-virtuous and happy. What we heard in England concerning the reformation of convicts in this colony was--fudge. They are as profligate and idle as the thieves and vagabonds of the United Kingdom. ${ }^{53}$

The true source and nature of this letter is unclear as two distinct versions appeared in the British press. One, printed in the Chronicle on 12 August 1829, foregrounded the state of the Aboriginal inhabitants. The other, printed-but not initiated-by the Scotsman, emphasised the state of the convicts and included the above description of their character. Thus, when it came to descriptions of transported convicts, the Scotsman continued to work outside its normal Australasian news network in order to provide a particular view on a particularly emotive issue.

After 1830, descriptions of convicts in Australia became infrequent. Occasionally a diverting biography or an account of an uprising on board a transport ship would appear, but more often the Scottish press referred to the process matter-of-factly, calculating the expense of transportation against the value of labour obtained. What is clear from the earlier burst of activity, however, is that the Scotsman was uncomfortable with the treatment of transported prisoners and the general ineffectiveness of colonial reformation, whereas the Mercury had a seemingly strong desire for the colony to succeed, both in the suppression of criminal tendencies and in the expansion of civilisation and trade. They curated their material carefully to offer these viewpoints, but neither succeeded in widely disseminating them. Instead, only occasional accounts of particular interest and authenticity managed to attract the attention the editors outside Edinburgh.

\section{Barbarity}

Although the fate of transported prisoners concerned the Edinburgh press, the most sensational, and reprinted, accounts were those describing the cruelty of native Australasians and the barbarity of Europeans who had given into their baser instincts; these tales of hostile encounters provide a number of intriguing glimpses into the identities of gatekeeper titles. ${ }^{54}$

In his discussion of settler discourse, Lester points a growing hostility to governments that, according to the Sydney Morning Herald, 'bestow so much of their pity on devastating and murdering savages, that they have none to spare for the white people. ${ }^{55}$ Although this trend is remarkably consistent within Lester's imperial network (comprised of the Herald, the New Zealand Chronicle and the Times), these sentiments are quite different from those expressed by the network presented here. Accounts of Aborigines reprinted in the eastern Scottish press

\footnotetext{
${ }^{52}$ Scotsman, 8 April 1826.

53 Scotsman, 15 August 1829.

${ }^{54}$ When speaking of pre-colonial inhabitants within greater the Australasian region, the term Australasians will be employed; the native inhabitants of Australia and Tasmania in particular will be referred to as Aborigines.

${ }^{55}$ Lester, p. 33.
} 
were frequently paternalistic, even sympathetic, to the inhabitants - at least in the abstract. They were described as 'very harmless', 'peaceable and friendly' and 'the most harmless inoffensive beings imaginable. ${ }^{56}$ It is also suggested on several occasions that their 'degraded position in the midst of the white population, affords no just criterion of their merits. ${ }^{.57}$ The purposeful decisions of these editors are particularly evident in the trial of seven transported prisoners for the murder of thirty Aborigines. Although accounts appeared in both the Sydney Herald and the Colonist, and both versions were received by Mercury, the latter referred to crime as a 'cold blooded massacre' and reprinted the Colonist, which was sympathetic to the murdered Aborigines, and excluded the Herald, which deemed the execution of the white prisoners outrageous. ${ }^{58}$ Nevertheless, specific outbreaks of violence were reported throughout the period. The earliest accounts, taken directly from the Gazette, often related violent confrontations between the settlers and Aborigines, but, by the 1830s, these narratives are generally absent from Australian accounts. As they fade, accounts of the rising conflict between the Maori and British in New Zealand do appear, but almost exclusively in the Scotsman, who appears far more interested in the southern colony than its rivals. ${ }^{59}$

Despite this relative tolerance, there was one supposed practice that continued to fascinate and horrify the Scottish editors: cannibalism. Whether cringing at its practice or praising its abolition, anthropophagy remained a consistent trope of Australasian news. Taken as a whole, the accounts that appeared in the Scottish press suggest that where the practice persisted, or was perceived to persist, the inhabitants were deemed cruel savages; where it had been abolished or had never been common, the light of civilisation shone upon them. The tale of Captain Samuel Fowler, master of the Indian brig Matilda, provides an illustrative example.

Sailing from Sydney in August 1813, five of Fowler's crew absconded when the ship arrived in the Marquesas Islands. Although Fowler himself was seemingly optimistic about Britain's civilizing mission, the account of his journey by the Gazette was decidedly more pessimistic. ${ }^{60}$ According to a November issue, the deserters, having joined forces with the native inhabitants, set the ship adrift, wrecking against the shore. 'When the cannibal natives saw that it was impracticable to get the vessel afloat, they concurred universally in the design of putting the whole of her crew to death, which appears to have been a constant practise among the different islanders towards one another. ${ }^{\prime 61}$ At this stage, the captain and part of his crew were saved by what the Gazette referred to as the local king. Developing a rapport with Fowler, 'he withheld his assent to the murder.' His compassion, however, was met with fierce opposition. When it became clear that he could not reason with his 'subjects', he tied ropes around the neck of his son and himself and asked that they would be strangled before the Europeans were killed, in order that he might die with a clear conscious. According the Gazette's editor, the

${ }^{56}$ CM, 20 December 1819; Scotsman, 24 September 1828; Scotsman , 13 March 1841.

57 Scotsman, 13 October 1838.

${ }^{58}$ CM, 13 June 1839. The Sydney Herald, 10 December 1838; The Colonist, 5 December 1838.

59 For a representative sample of reportage on New Zealand conflicts, see Scotsman 7 November 1829,11 May 1842 and 20 December 1843.

${ }^{60}$ For a representative selection of Fowler's encounters and impressions in New Zealand, see Peter Entwisle, Taka: A Vignette Life of William Tucker 1784-1817: Convict, Sealer, Trader in Human Heads, Otago Settler, New Zealand's First Art Dealer (Dunedin: Port Daniel Press, 2005), pp. 85-6.

${ }^{61}$ SG, 8 November 1815. 
'magnanimity of such a conduct could not do less than produce, even in the mind of the unenlightened savage, a paroxysm of surprise, mingled with a sentiment of admiration in which the untaught man may possibly excel his fellow creature'. Moved by his words, and horrified at the prospect of his murder, his 'subjects' spared the lives of Fowler and his men. The piece, as it appeared in New South Wales, clearly provided a negative view of the native inhabitants of the South Pacific. Yet, it also demonstrated that civilised conduct could be induced from them, under the certain conditions. Indeed, the piece was immediately followed by a wholly unrelated, but generally positive, account of trade between Fowler and other Marquesas peoples. How this latter impression translated as it filtered across the Atlantic confirms the importance of gatekeeper editors.

The story first appeared in the Gazette in late 1815. In January 1817, it reappeared in London's Courier. Although the main text was identical, an important decision had been made regarding its title. Whereas the Gazette had attached no headline to the piece, as was typical of its accounts, the Courier chose to use 'ANOTHER DREADFUL MASSACRE BY THE NATIVES OF THE MARQUESAS ISLANDS' - a choice that placed a very particular spin on the story, one that was maintained when the piece was reprinted in the Scottish press, with its new title, four days later. ${ }^{62}$ Yet, this decision should not imply that the harrowing portrayal was entirely effected by the Courier. Fowler's normally approving opinion of Pacific Islanders, and their suitability for Christian civilisation, was first overruled by the Howe. Instead of concluding his commentary with the crew's return to the friendly Port Anna Maria, and Fowler's observations of their eagerness to trade, it ended with the views of an unnamed missionary who described the local inhabitants as a 'people constantly studying their thoughts on plunder, and devising schemes for taking advantage of strangers. ${ }^{163}$

Despite the congruity of the Courier's headline with Gazette's sentiment, the addition did not sit well with everyone. For example, The Percy Anecdotes, a literary digest printed in 1832, chose the headline 'Magnanimity of a Savage King'. ${ }^{64}$ As for Scotland, despite the title being maintained by the Mercury, the inflammatory nature of the headline was deemed unsuitable for the church-minded Aberdeen Journal, who reduced it to 'DREADFUL MASSACRE BY THE NATIVES OF THE MARQUESAS ISLANDS', removing the suggestion that this was but one in a long line of brutal acts of cannibalism. This small alteration did not, however, prevent them from truncating the piece to conclude with the Gazette's explicit account of the savage act. " $A$ native man belonging to Port Anna Maria, who was not tattooed, and in consequence prohibited from the eating of human flesh, on pain of death, impatient of the restraint, fell upon one of the murdered bodies, and darting his teeth into it in all the madness of a voracious fury, exhaled the crimson moisture, which had not yet coagulated."65

From its origins in New South Wales, through its republication across the Atlantic, the text

\footnotetext{
${ }^{62}$ Courier, 2 January 1817; CM, 6 January 1817.

${ }^{63}$ SG, 8 November 1815;

${ }^{64}$ Thomas Thomas Byerley and Joseph Clinton Robertson, The Percy Anecdotes: To Which Is Added a Valuable Collection of American Anecdotes: Original and Select, Illustrated with Fourteen Fine Portraits (London: J.J. Harper, 1832), p. 198.

${ }^{65}$ AJ, 8 January 1817.
} 
remained true to that of the Gazette. ${ }^{66}$ Despite being retitled by the Courier, or truncated by the Aberdeen Journal, it was Howe who dictated the precise image that Scottish readers would obtain of the native inhabitants of the Antipodes, an image that would endure until its loss of exclusivity in the late 1820 s.

The act of cannibalism, often described as the consumption of an enemy's flesh, was often attributed to the inhabitants of South Pacific. ${ }^{67}$ Although the validity of these claims has been frequently disputed, or heavily qualified, anthropologists such as Gananth Obeyesekere feel that this commentary says more about inter-cultural relations than the act of anthropophagy itself. ${ }^{68}$ The British obsession with cannibalism, as he classifies it, suggests a growing unease with Britain's own history and practices. As early as the seventeenth century, European custom of the sea had allowed for the consumption of human flesh in the case of shipwreck or maritime disaster. ${ }^{69}$ Although repeatedly condemned by the British public, it was not until $R v$ Dudley and Stephens (1884) that necessity was explicitly rejected as a defence of murder in common law. ${ }^{70}$ Of course, accounts of European cannibalism were not confined to shipboard anthropophagy. As a penal colony, New South Wales allowed for the horrors of cannibalism to be embodied by another other; transported convicts. Thus, during the Gazette's run, two cases of Australasian cannibalism were brought before the court of Scottish public opinion: The shipwreck of the Essex and the trial of Alexander Pearce.

The tale of Captain George Pollard, Jr and his ill-fated Essex first appeared in Britain in the pages of the Chronicle on 17 December 1821, before being reprinted three days later in the Mercury. ${ }^{71}$ The text, taken directly from the Gazette, recounts the unexpected destruction of the Essex by an enraged sperm whale (the inspiration for Melville's Moby Dick), the scattering of the crew into small boats, their struggle to survive with diminishing provisions, and their ultimate decision to engage in cannibalism. The gatekeeper role of the Gazette is particularly evident in this case. With little regard for chronology, the Gazette compiled the copy as news arrived from various quayside sources-a method of compilation similar to that practiced by the British provincial press, in which each day's London dispatches were appended to end of the text until the page was filled. ${ }^{72}$ What is important is that neither the Chronicle nor the Mercury chose to reorder or otherwise rewrite the account. Instead, the ever increasing feeling of dread, the suspicion that each paragraph might bring even more horrifying details, was

\footnotetext{
${ }^{66}$ The account, as written in the Courier, appeared in a number of North American titles over several months. These typically removed the emotive headline, replacing it with the more description 'From the London Courier, Jan. 2'.

${ }^{67}$ For an example of this distinction, see $C M, 23$ January 1843.

${ }^{68}$ Gananath Obeyesekere, "'British Cannibals": Contemplation of an Event in the Death and Resurrection of James Cook, Explorer', Critical Inquiry, 18 (1992), 630-54 (pp. 630-1).

${ }^{69}$ For early accounts the British practice of cannibalism in instances of shipwreck, see Allan C. Hutchinson, Is Eating People Wrong?: Great Legal Cases and How They Shaped the World (Cambridge University Press, 2010), p. 19 and A. W. Brian Simpson, Cannibalism and Common Law: A Victorian Yachting Tragedy (London: Continuum International Publishing Group, 2003), pp. 122-7.

${ }^{70}$ Katherine Biber, 'Cannibals and Colonialism', Sydney Law Review, 27 (2005), 623-637 (p. 632).

${ }^{71}$ MC, 18 December 1821; CM, 20 December 1821.

${ }^{72}$ SG, 9 June 1821; Charles E. Clark, The Public Prints: The Newspaper in Anglo-American Culture, 1665-1740 (New York: Oxford University Press, USA, 1994), p. 61.
} 
maintained, despite the opportunity to restructure the piece into a more cohesive narrative. Thus, the Gazette maintained ultimate authority on the manner in which this case of customary cannibalism was portrayed at home and abroad. This is, in no small part, because of the Chronicle's preference for direct transcription of Australasian content. Like many of its metropolitan competitors, it required a significant amount of editorial content to fill its twenty daily columns. Haphazard though its composition may have been, the Gazette's account offered a full column of text, ready for typesetting. ${ }^{73}$ As for the Mercury, its reluctance to alter the Chronicle's text may have resulted from its lack of direct access to the Gazette, and therefore a scarcity of contextual details. The case of Alexander Pearce, reported just four years later, presents a somewhat different picture.

According to his confession, reprinted in the Chronicle, Alexander Pearce was born in the north of Ireland and transported for seven years for 'stealing six pairs of shoes'. ${ }^{74}$ During his transportation he had several run-ins with colonial authorities, escaping and being recaptured on numerous occasions. It was during one such escape that Pearce's claim to notoriety began. As Pearce and seven fellow convicts attempted to evade recapture, they ran dangerously low on provisions and, like Pollard's men, settled upon the idea of drawing lots. Having survived upon the flesh their unlucky compatriot 'as long as it lasted', Pearce and others again drew lots, reducing their numbers until Pearce alone remained. Importantly, Pearce claimed that the final death was self-defence as his companion 'always carried the axe' and, Pearce believed, waited for an opportunity to kill him. Alone and low on provisions, Pearce resolved to surrender himself to the authorities, when he came upon two new fugitives with whom he continued his escape before finally being recaptured and returned to Hobart Town gaol. As may be expected, he escaped once more, this time with a man named Thomas Cox. When the two men approached a river obstructing their flight, Cox admitted that he could not swim. The men quarrelled and Cox succumbed to an untimely and painfully prolonged death from Pearce's axe. Previous experience having taught him the value of maintaining provisions, the fugitive butchered Cox's remains and continued onward. At this stage, he confessed that his 'heart failed' and he decided to surrender once again. After a sensational trial, he was executed for murder on 19 July $1824 .^{75}$

This abhorrent account of murder and cannibalism spread in a number of different ways. First, the court proceedings appeared in the local Hobart Town Gazette and Van Diemen's Land Advertiser between June and August 1824. These were extracted by the Sydney Gazette, but it was the original account that travelled back to Britain. An arrangement of these extracts, supplemented with an additional version of Pearce's confession, appeared in London in January $1825 .^{76}$ This compilation was then reprinted by the Scotsman, but only the inserted confession, rather than that which had appeared in the Hobart Town Gazette, was included. ${ }^{77}$ This second

\footnotetext{
${ }^{73}$ R. M. Wiles, Serial Publication in England Before 1750 (Cambridge University Press, 2012), p. 31.

${ }^{74}$ MC, 8 January 1825.

75 The Hobart Town Gazette and Van Diemen's Land Advertiser, 23 July 1824.

${ }^{76} M C, 8$ January 1825.

77 Scotsman, 12 January 1825. The two confessions reprinted in the British press contain several contradictions with each other and other known confessions by Pearce. For a reconciliation of these texts, see Dan Sprod, Alexander Pearce of Macquarie Harbour: Convict-Bushranger-Cannibal (Hobart: Cat \& Fiddle Press, 1977).
} 
arrangement was then reprinted by the Kelso Mail and the Berwick Advertiser before fading out of the periodical press. This inserted confession, stripped of its contextual material, continued to appear in various literary digests over the next fifteen years, including The Terrific Register; or, Records of Crime, Judgements, Providences and Calamities. ${ }^{78}$

Like Pollard's account, the main text had its origin in the Australasia press; it was, in the main, the Australasian editor who dictated the nature and language. Once it reached London, however, an additional, first-person version of Pearce's confession was appended. Moreover, once the tale reached Scotland, the third-person confession was omitted, while the other remained. Thus, although the language was wholly taken from Australasian writers, its presentation was clearly shaped by the London and Edinburgh press.

The fact that the Scotsman maintained the first-person confession may have affected how its readership perceived the condemned. In his study of the trial of Charles I, and the newspaper accounts thereof, Brownless suggested that 'the more access the reader has to the speaker's exact words the more positively and sympathetically the reader will evaluate those words. ${ }^{79}$ By hearing Pearce explain, in direct speech, his repeated decisions to surrender himself, especially when his 'heart failed' him after murdering Cox, the reader is more likely to accept his contrition. Although this version deemed him no less worthy of his sentence, this subtle glimpse into Pearce's humanity by the British press is noteworthy.

\section{Damnation}

Alexander Pierce was not the only unredeemed convict to appear in the Australasian press. Indeed, in the first decades of the nineteenth century, numerous transported prisoners fled their assigned labour placements, or their places of imprisonment, to survive on the edge of Australasian settlements. ${ }^{80}$ Within the Australian press, the height of their notoriety was in the mid-1810s, when 'bush rangers' were mentioned in over twelve per cent of issues, with a secondary peak in the mid-1820s. ${ }^{81}$ In Scotland, the appearance of bush rangers generally coincided with these spikes, but their prominence in the Scottish press was not necessarily proportional because of anomalies within their dissemination pathways.

The initial flurry, in the second half of the 1810s, presented the bush rangers in a number of different ways. In 1814, the Mercury first broached the subject by reprinting a letter by an unidentified correspondent. Bush rangers, whom it identified as 'convicts who have escaped into the woods and live on kangaroos', were blamed for the lack of positive interaction between British colonists and Aborigines, as the fugitives 'frequently shoot them without cause. $^{\prime 82}$ The danger posed to white settlers, however, was evidently quite low, as the writer

\footnotetext{
${ }^{78}$ The Terrific Register: Or, Record of Crimes, Judgments, Providences, and Calamities ... (Sherwood, Jones, and Company, 1825), pp. 84-6.

${ }^{79}$ Nicholas Brownlees, 'Spoken Discourse in Early English Newspapers', Media History, 11 (2005), 69-85 (p. 79).

${ }^{80}$ Paula J. Byrne, "The Public Good": Competing Visions of Freedom in Early Colonial New South Wales', Labour History, 1990, 76-83 (p. 79).

81 This is based upon the number of instances of the term 'bush ranger' (and reasonable variants) within the National Library of Australia's digital newspaper archive. As no issue had more than one article containing the term, and all relevant issues for this period have been digitized, a comparable percentage can be derived.

${ }^{82}$ CM, 26 May 1814
} 
quickly moved onto other topics. In an article printed the following year, the Mercury referred to them as brush rangers and precise details of their activities remained elusive; however, they were becoming a more pressing concern in the 'back settlements' where, 'sheltered by the difficult nature of the country, [they] daily committed atrocious murders on the unwary traveller. ${ }^{83}$ These two accounts, the earliest to appear within this network, are noteworthy because they were not reprints from the Chronicle. Although the introductory comments suggest the second piece is a reprint from The Englishman, neither piece appeared in any of the London titles from which the Mercury generally harvested its content in the 1810s. Indeed, the Post does not mention bush rangers prior to 1818, and the Chronicle, Scotland's primary source for early Australasian news, does not do so until $1826 .{ }^{84}$

Despite a lack of content from their primary ports of call, the Scottish press pressed on. By 1817, conflict between the colonial authorities and 'these miscreants' had reach a head, and the Scotsman noted that Governor MacQuarrie had denounced thirty-four such individuals and prohibited 'armed bands' from appearing in Sydney or the neighbouring settlements. ${ }^{85}$ The following year, the Mercury informed its readers that a 'gang of armed banditti, appropriately called the Bush Rangers, headed by Peter Geary, a deserter from the 73d regiment, has had a regular combat with a serjeant's party of the 46th, in which Geary fell, and two others were wounded. ${ }^{86}$ Four years later, William Geary, another bush ranger, was reported as terrorizing the Australian countryside, but, unlike his predecessor, had escaped his encounters unharmed. ${ }^{87}$

These three accounts represent an important trend in dissemination pathways. The first was a digest from several issues of the Sydney Gazette from mid-1816, collated by either the Scotsman or an unidentified third party; little of the original language is discernible and the breadth of content is greatly reduced. The second, on the other hand, had a longer but less perilous path. This account appeared as part of a series on the Howe-Geary gang in the Hobart Town Gazette and Southern Reporter in July 1817. This series was later abridged by the Sydney Gazette. The British Press, or Morning Literary Advertiser then digested several issues of the Sydney Gazette, alongside additional content, and this summary was reprinted by the Mercury, followed by the Berwick Advertiser a week later. ${ }^{88}$ The third piece was also a digest of Sydney Gazette material, but remained perfectly intact with no additional material appended from other sources. ${ }^{89}$ The role of the Sydney Gazette in the presentation of Australia's early outlaws is thus remarkably diluted. Because these earliest encounters defy established pathways for Australasian intelligence, Howe's unadulterated voice is lost. Unlike the Chronicle and Post, which privileged and reprinted Gazette reports with little if any alteration, the Englishman, British Press and other providers took a very different tact.

\footnotetext{
${ }^{83}$ CM, 23 November 1815.

${ }^{84}$ Morning Post, 5 January 1818; MC, 5 July 1826.

${ }^{85}$ Scotsman, 3 May 1817.

${ }^{86} \mathrm{CM}, 4$ July 1818.

${ }^{87} \mathrm{CM}, 7$ January 1822.

${ }^{88}$ The Hobart Town Gazette and Southern Reporter, 5 July 1817, 12 July 1817; SG, 4 October 1817; The British Press, or Morning Literary Advertiser, 30 June 1818; CM, 4 July 1818; BA, 11 July 1818.

${ }^{89}$ SG, 21 July 1821.
} 
One consequence of these multiple abridgements is the lack of individuality amongst the bush rangers. Although the nefarious character of Peter Geary is well established by Mercury in 1818, the true leader of this gang, Michael Howe, is never mentioned, despite his more frequent appearance in the Gazette. Likewise, though the Geary referred to in 1822 is a wholly different individual, and alternative narratives about Australian bush-ranging were available to the Scottish public, a casual reader might be forgiven for thinking Peter Geary had returned from perdition to once again roam the Australian back-country. ${ }^{90}$ These accounts, critical to Scottish understanding of Australian society, portrayed run-away convicts as dangerous and bloodthirsty outlaws, a characterisation quite different from that held by members of Australia's own convict community, who often considered them heroic martyrs, for 'none are so much talked of for their generosity, their invariable respect and tenderness for women and children as Mike Howe'. ${ }^{91}$

Nothing more is heard of the bush rangers until the summer of 1826, when a story from the Colonial Times and Tasmanian Advertiser finds its way to Scotland; it does so along two separate paths, both beginning in London. In one case, a set of the Colonial Times reached the Chronicle and was reprinted in its entirety. ${ }^{92}$ The news that that 'all but three' of the bush rangers tormenting Van Diemen's Land were 'either taken or destroyed' then appeared in the Glasgow Herald five days later. ${ }^{93}$ Meanwhile, a similar set of the Colonial Times was digested by the London Times. Its brief summary triumphantly announces 'the extermination of the bush rangers' and this news is reprinted by several other Tory papers, including the Edinburgh Advertiser and the Kelso Mail. ${ }^{94}$ Although the Gazette is seemingly absent from this scenario, its role is nonetheless clarified by these dissemination pathways. Although the news from Hobart took two discrete paths from London to Scotland, in only one was its voice preserved. The Chronicle, for its own reasons, continued to extract whole articles from its Australasian sources, which were in turn reprinted north of the Tweed. The Times, however, asserted its own voice over that of the Colonial Times, placing its own spin on the news. That the Sydney Gazette had been reprinted so faithfully in previous years, therefore, suggests more about the role of the London press than that of their Sydney suppliers.

These accounts of the demise of bush-ranging were further corroborated by a letter received by the Edinburgh Advertiser, which reassured readers 'who have relations or friends in Van Diemen's Land' that the danger of 'robberies and murders' had in large part subsided; the good news was also printed by the Scotsman, Caledonian Mercury, and Kelso Mail over the following weeks. ${ }^{95}$ This letter is notable as it was one the first pieces of the correspondence to be sent to directly to Edinburgh, rather than via London, and then be widely distributed among the Scottish press. Over the next ten years, news of bush rangers appeared almost exclusively in

\footnotetext{
${ }^{90}$ For example, extracts of Thomas E. Wells, Michael Howe, the Last and Worst of the Bush Rangers of Van Diemen's Land (Hobart Town: Alan Bent, 1818) were printed in The London Quarterly Review (Theodore Foster, 1820), pp. 73-83, a periodical readily available to Scottish readers, if less influential than its Edinburgh rival.

${ }^{91}$ Graham Seal, The Outlaw Legend: A Cultural Tradition in Britain, America and Australia (Cambridge: Cambridge University Press, 1996), pp. 119-121.

${ }^{92}$ CT, 31 March 1826; MC, 23 August 1826.

${ }^{93}$ Glasgow Herald, 28 August 1826.

${ }^{94}$ The Times, 23 August 1826; KM, 28 August 1826; EA, 29 August 1826.

${ }^{95}$ EA, 1 September 1826; Scotsman, 2 September 1826; CM, 4 September 1826; KM, 14 September 1826.
} 
the Scotsman, and it, in the main, continued to receive and digest this type of news directly from correspondents and independent Australasian newspapers; namely those from Hobart. ${ }^{96}$ As with convicts and cannibals, accounts of bush-ranging that were written by the Gazette and curated by London, had faded from the Scottish press by the mid-1820s.

The last spate of bush-ranging accounts appeared in the early 1840s, when a number of incidents took place in the younger colony of South Australia. ${ }^{97}$ At this stage, the Scotsman ceased to comment on the phenomenon, leaving its cross-town rival, the Mercury, to keep the narrative alive. Like the Scotsman, it now relied directly upon Australian papers, rather than London digests. Unlike the Scotsman, its primary contacts were in Port-Philip, and these papers and correspondents, rather than government voice of Sydney, or the inhabitants of Van Diemen's Land, dictated the tone and nature of bush-ranger lore in 1840s Midlothian. ${ }^{98}$

\section{Conclusion}

The role of the Sydney Gazette in the Scottish public sphere was both crucial and limited. Despite its lack of competition before 1821, it was never the lone narrator; commentaries from younger presses and settler correspondence enhanced, and contradicted, the image it presented, while British writers supported and rebutted Australasian claims. Yet, in these cases at least, the voices of Australasia were the most likely to be reprinted and to survive intact. As the Gazette was Britain's most consistent stream of Australasian opinion for over twenty years, it continued to influence the narrative, whether it was fit to do so or not.

As for London, its role was often curtailed by metropolitan competition and the practicalities of daily publication. Although it filtered the content it received, the Chronicle and the Post usually strengthened the Gazette's role by privileging its voice above those of the newer presses or even their own.

Finally, the agendas and contacts of the Edinburgh papers played an increasingly critical role in shaping Scottish opinion. These presses consistently valued and privileged authentic Australasian voices over British commentary, and sought them out when they were not provided through standard domestic channels. More importantly, they were discerning in what they deemed authentic, developing independent and individual contacts within the Australasian colonies. As these developed, diverged, and dissipated, their conception of Australia evolved, becoming, at least in part, a Scottish creation.

\footnotetext{
${ }^{96}$ See, for example, Scotsman, 27 June 1827, 12 August 1829 and 11 January 1834.

${ }^{97}$ Scotsman, 29 July 1849; CM 1 August 1840. Bush-ranging would again become a popular discourse in the 1870s with the rise of Ned Kelly.

${ }^{98} \mathrm{CM}, 5$ September 1840; 11 January 1841. Although the article printed in 1840 first appeared in the $M C$, the London paper made several transcription errors, including the date of the piece, which were not present in the $C M$, suggesting the latter had direct access to the Port-Philip Patriot, from which the piece is derived.
} 